Research Article / Araşttrma Makalesi

\title{
SUSTAINABLE HUMAN RESOURCES MANAGEMENT (HRM) A STUDY IN TURKEY CONTEXT AND DEVELOPING A SUSTAINABLE HRM QUESTIONNAIRE*
}

\author{
PhD Dilek ESEN** \\ Dokuz Eylül University, İzmir Vocational School, İzmir, Turkey, (dilek.esen@deu.edu.tr) \\ Prof. Dr. PInar SÜRAL ÖZER \\ Dokuz Eylül University, FEAS, İzmir, Turkey, (pinar.ozer@deu.edu.tr)
}

\begin{abstract}
This paper tries to indicate a general framework about Sustainable Human Resources Management (HRM) practices of businesses in Turkey. For this purpose, the meaning and content of sustainable HRM, its prominent dimensions and current situation of its practices in businesses were questioned. The study was carried out with the explanatory design. The data were collected in 3 stages. In the first stage, the content analysis of the sustainability reports of 93 businesses was carried out by using Maxqda within the context of HRM. In the second stage, Delphi method was implemented with participation of 22 experts. In the third stage, the current situation of Sustainable HRM practices was analyzed. The Sustainable HRM questionnaire was developed by the researcher based on the findings of previous phases.
\end{abstract}

Keywords: Sustainability, Human Resources Management, Sustainability Reports, Sustainable Human Resources Management.

\section{SÜRDÜRÜLEBILIR İNSAN KAYNAKLARI YÖNETIMİ (IKKY) TÜRKIYYE BAĞLAMINDA BİR ARAŞTIRMA VE SÜRDÜRÜLEBİLIIR IKKY SORU FORMU GELIŞTIRME}

\begin{abstract}
ÖZET
Bu çalışma, Türkiye'de faaliyet gösteren işletmelerin Sürdürülebilir İnsan Kaynaklart ile ilgili çalışmalarına iliş̧kin genel bir çerçeve sunmak üzerine kurgulanmıştır. Bu amaçla Sürdürülebilir İKY'nin anlamı ve içeriği, öne çıkan yönleri ve işletmelerdeki uygulamaların mevcut durumu sorgulanmıştır. Çalışma açımlayıcı desen yöntemine uygun yürütüllmüsştür. Veriler üç aşamada toplanmıştır. İlk aşamada, 93 işletmenin sürdürülebilirlik raporlarının IKY ile ilgili kısımları, Maxqda kullanılarak içerik analizi yöntemiyle incelenmiştir. İkinci aşamada, 22 uzmanın katılımıyla Delphi yöntemi uygulanmıştır. Üçüncü aşamada, Sürdürülebilir IKY uygulamalarının mevcut durumu analiz edilmiştir. Sürdürülebilir IKY soru formu önceki aşamalardan elde edilen bulgulardan yararlanarak, araştırmacı tarafından geliştirilmiştir.
\end{abstract} Anahtar Kelimeler: Sürdürülebilirlik, İnsan Kaynakları Yönetimi, Sürdürülebilirlik Raporları, Sürdürülebilir İnsan Kaynakları Yönetimi.

* This study is produced from the doctoral thesis of the first author.

** Corresponding author

www.ijmeb.org ISSN:2147-9208 E-ISSN:2147-9194

http://dx.doi.org/10.17130/ijmeb.798548

Received: 03.02.2020, Accepted: 28.04.2020

Ethics Committee Name: Dokuz Eylül University, Social Sciences and Humanities Research and Publication

Ethics Committee, Date: 25.09.2020, Number No: 5 


\section{Introduction}

Due to developments in practice and theory, the field of human resources management has been subjected to paradigmatic changes. Approaches considering human beings as a resource by separating them from any physical presence of organization and attributing a strategic importance in such a competitive environment have continued within those changes. During this course, the concepts used for defining human resources management have begun to be defined as personnel management, human resources management and strategic human resources management to replace each other and expand their concepts.

However, in today's world, the approach of considering humans as strategic resources has been replaced with the approach of seeing them as sustainable (required to be sustainable), creative, and unique beings. In addition, ecological problems, increasing inequality among people (Vehkamaki, 2005), factors resulting from the internationalization or globalization of businesses, ageing workforce, developments in the market, increasing psychosocial risk factors and busy schedules (Ehnert, 2009), new generation employment contracts, lack of job security, having a heavy emotional burden at work, work-life imbalance (Van Stolk et al., 2012), human resources exploitation (Ehnert, 2009), importance of establishing innovative organizations (Zang et al., 2019) make it necessary that the management of sustainability and human resources are addressed and dealt together .

Difficulty of having the sufficient number of highly qualified/skilled and motivated staff in the right place at the right time, has been gradually increasing for HR managers (Scherm, 1999; as cited by Ehnert, 2009 from Thom \& Zaugg, 2004). At this point, the issue in question is not lack of human resources, but lack of human resources with desired quality and skills (Ehnert, 2009). Another variable that is important for sustainable HRM is the evolution of economies into a knowledge-based understanding. The demand for highly qualified and skilled human resources has been increasing in knowledge-based economies as this kind of HR is essential for a sustainable competitive advantage.

Sustainable HRM indicates that, human resources practices provide a basis in order to develop the desired human skills and to compensate the ecological, demographical and social pressures under the existing circumstances (Wilkinson et al., 2001). Sustainable HRM, does not only serve for the purpose of accomplishing organizational goals of existing and planned human resources strategies but also minimizes negative effects of these strategies on natural resources, individuals and society (Ehnert, 2009; Kramar, 2014). As Stankevicite \& Savanevicien (2018) mentioned, Sustainable HRM must have some special characteristics, like long term orientation, care of employees, care of environment, profitability, employee participation and social dialogue, employee development, external partnership, flexibility, compliance beyond labor regulations, employee cooperation, fairness and equality.

A particular attention drawn to sustainable HR has begun increasing on the international level by 2000s (Pfeffer, 2010) and within the context of Turkey since 2010. It is seen that cognitive and qualitative methods are preferred for the studies carried out within this context and the researches where quantitative methods are used are quite limited (Kramar, 2014).

In this study, it is aimed to establish a conceptual framework for Sustainable HRM within the context of Turkey and determine the prominent HRM subjects among sustainability 
reports, Sustainable HRM activities of personnel and their perception of their dimensions and the existing situation of Sustainable HRM in business practices. Within this context, the questions, we search for answers as follows:

a. How is Sustainable HRM represented conceptually and how is it perceived?

b. What are the prominent HRM practices within the frame of Sustainable HRM?

c. What are the dimensions of Sustainable HRM?

d. What is the existing situation of Sustainable HRM in business practices?

e. Is it possible to provide a basis to develop an assessment instrument for Sustainable HRM?

Accordingly, it is considered that it will be useful for the academicians desiring to carry out benchmark studies particularly within the context of cultures to present the existing situation of Sustainable HRM in Turkey. In addition, the questionnaire of Sustainable HRM is expected to be useful for both the academicians and practitioners who would like to study in the field of Sustainable HRM by using quantitative methods.

\section{Literature Review}

\subsection{Sustainable Human Resource Management}

As there is not a common shared definition for the Sustainable HRM in the literature, one of the main questions that needs to be answered for the people interested in the subject is "What does Sustainable HRM represent?". Is Sustainable HRM an old wine in a new bottle? Is it a fashion or just a concept? (Savaneviciene \& Stankeviciute, 2014). Ehnert et al., (2014) consider Sustainable HRM as a new paradigm and a new understanding for HRM, De Prins et al., (2014) as a promising field for theorization, research and practice, Kramar (2014) as a new approach used for managing human resources by extending the purposes of HRM and Ehnert (2011) as an understanding broader than the Strategic HRM.

Ehnert \& Harry (2012), expresses why sustainability is related with the functions of HRM and the importance of sustainability in HRM through two different perspectives. One of the dimensions of these arguments is the macro perspective which dwells on the contributions of organizations on their social and economic spheres. This perspective is usually associated with social and ecological sustainability arguments. According to this notion, sustainable contributions of organizations in social and ecologic spheres are provided through HRM practices. Another dimension of these arguments focuses on the inherent factors and relations within HRM system and discusses sustainability in individual and HRM levels (micro level). Arguments in this perspective are associated with lack of human resources, ageing workforce and increasing occupational health problems and consider sustainability of HRM system as a “vital strategy" for organizations (Ehnert \& Harry, 2012).

Whether addressed in the macro or micro level, the fundamental element of the process is "human". Consequently, the process will start with "human" namely, individual sustainable behavior (Lülfs \& Hahn, 2014) and end with "human" (Cavagnaro \& Curiel, 2012). It will be possible through small changes namely changes at individual level to carry out sustainability activities at corporate level, in other words to implement big changes. The main purpose of 
sustainable development is to continue economic development, present equalitarian social life and provide ecological protection in order to secure a higher-quality life for current and future generations. These three dimensions bring sustainable societies along with it. And it is impossible to achieve sustainable societies unless organizations and individuals do not become a part of these projects (Cavagnaro \& Curiel, 2012).

Sustainable HRM is the long-term harmony of recruitment, selection, training and development processes of human resources and implementation of human resources activities in accordance with the principles of social responsibility and economy (Thom \& Zaugg, 2004). Based on the studies carried out before, the following conceptual model of Sustainable HRM can be represented as Figure 1.

\section{Figure 1: Conceptual Model of Sustainable HRM}

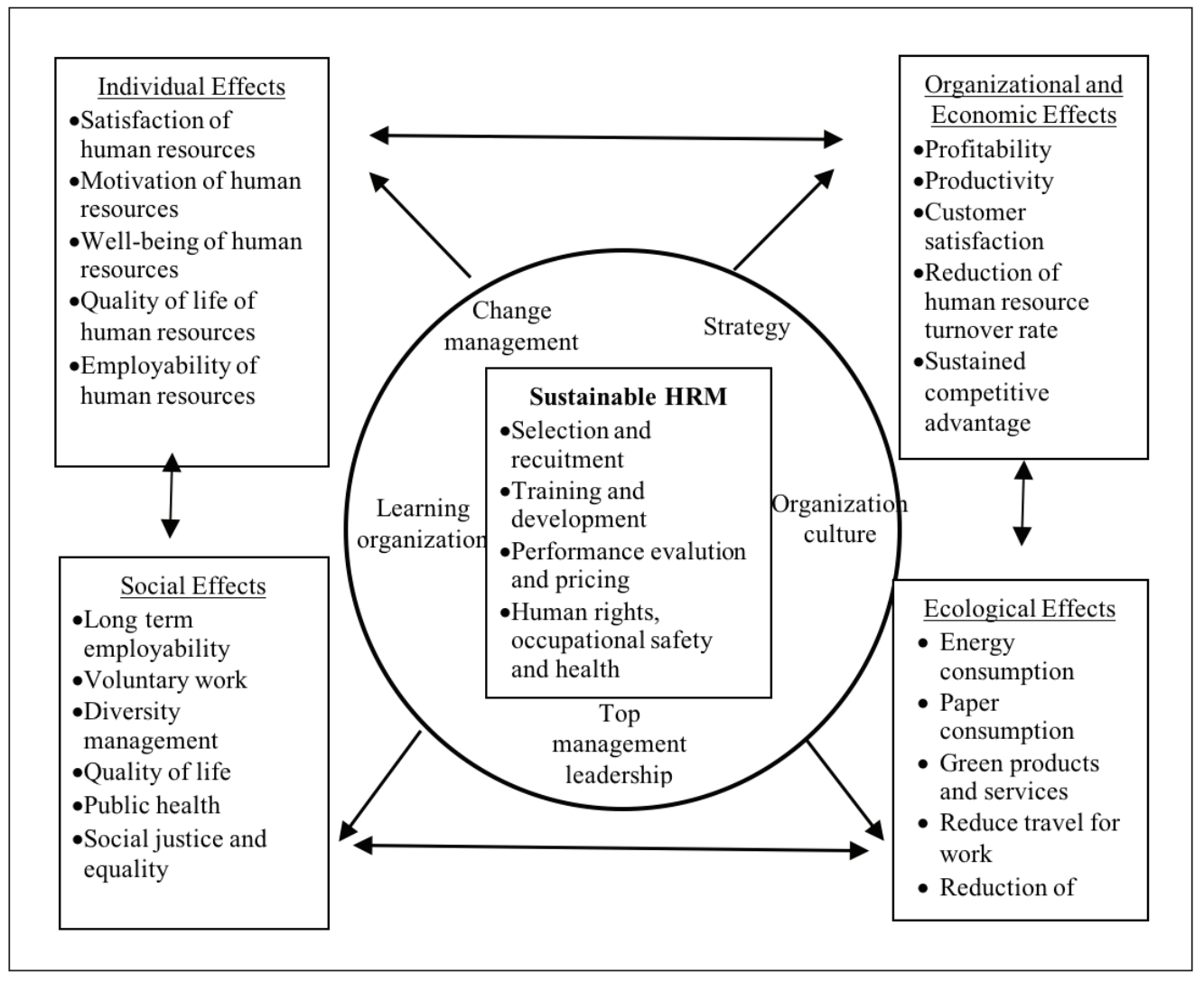

In the literature of Sustainable HRM, while a group of authors address Sustainable HRM with regards to the functions of HRM (Tang et al., 2017; Jerome 2013; Jepsen \& Grob, 2015), another group address sustainability around certain topics. Employability, individual responsibility, work-life balance (Zaugg et al., 2001; Esfahani et al., 2017; Prins et al., 2014), career development and workplace related regulations (Gollan, 2005), development of 
employees, flexible working practices, managing diversity, voluntary participation in social projects, employees' (physical and psychological) health, green HRM (Rompa, 2011; Prins et al., 2014), ageing workforce, ecological stakeholders, labor market, workplace innovation (Prins et al., 2014), justice and equality, transparent HR practices, profitability and subjective well-being (Jarlström et al., 2016) are within the context of these topics.

International studies on Sustainable HRM can generally be represented under three main topics. The studies within the first group of these topics are built on establishing a relationship between Sustainability and HRM, the importance of sustainability for HRM, difference of Sustainable HRM from other concepts and discussing the concept of Sustainable HRM (Zaugg et al., 2001; Gollan, 2000; Wilkinson et al., 2001; Stankeviciute \& Savaneviciene, 2013; Kramar, 2014; Jepsen \& Grob, 2015). It is considered that these studies have been influenced from issues such as ecological management, corporate social responsibility, human resources relations, problems experienced in finding qualified human resources and etc. Ina Ehnert has associated Sustainability with HRM and made several studies providing significant contributions for discussing it as a new concept and approach (Ehnert, 2006, 2009, 2011, 2012, 2014). The second group activities contributed in development of the Sustainable HRM literature question and address Sustainable HRM with social and organizational concepts or issues (Mariappanadar, 2003; Mariappanadar \& Kramar, 2014; Wilkinson et al., 2001; Pfeffer, 2010). In these studies, Sustainable HRM has been discussed by associating with topics such as talent management (Boudreau, 2003; Boudreau \& Ramstad, 2005; App et al., 2012), employer brand (Stefaine et al., 2012), organizational performance (Jerome, 2013), innovative enterprises, flexibility of HR and psychological capital (Esfahani et al., 2017), analyzing Sustainable HRM in the frame of model enterprises (Mejias et al., 2015; Wirtenberg et al., 2007), importance of being sustainable for humans (Pfeffer, 2010) and etc. In the third group activities of the Sustainable HRM literature, the role assigned to HRM expands in contemplation of making enterprises sustainable and responsible not only economically or socially but also ecologically (such as Daily \& Huang, 2001; Jabbour \& Jabbour, 2016; Masri \& Jaaron, 2017; Tang et al., 2017 and etc.).

Within the context of Turkey, limited number of studies on Sustainable HRM are conceptual studies generally related with understanding the relation between Sustainability and HRM and describing Sustainable HRM (ILO, 2005; Özutku et al., 2015; Kesen, 2016; Uslu \& Kedikli, 2017; Kılıç \& Vatansever, 2017; Pekdemir, 2017; Vatansever et al., 2017; Dinler, 2018). During the analyses, it draws attention that the studies on Green HRM which is a part of the ecological dimension of Sustainable HRM are more in the literature.

\subsection{Phases of the Study}

The study consists of three consecutive phases. Respectively, these phases are analyzing sustainability reports through content analysis method, getting expert opinions through Delphi technique and scale development activities for Sustainable HRM.

In the first phase, the HRM related parts of sustainability reports have been examined through content analysis method. The aim of these phase is, determine the prominent HRM issues in supporting sustainability activities by examining the HRM related parts of sustainability reports. 
In the second phase, by means of the findings obtained in first phase, the Sustainable HRM Delphi technique study has been conducted. In the Delphi technique study, Sustainable HRM concept and the dimensions of Sustainable HRM have been addressed by getting opinions from 22 experts.

In the third phase, by means of the findings obtained from the first two phases, a questionnaire development study on Sustainable HRM has been conducted. In this phase, the perception for importance of the HRM practices was questioned in terms Sustainable HRM. Also, it was intended to determine whether there are any Sustainable HRM practices and strategic level of sustainability in enterprises and the driving and facilitating forces of sustainability practices.

\subsubsection{First Phase: Examining Sustainability Reports within the Context of Sustainable Human Resources Management}

\subsubsection{Research Method of the First Phase}

In this phase, it is aimed to determine the prominent HRM issues in supporting sustainability activities by examining the HRM related parts of sustainability reports through content analysis method. While, enterprises get feedbacks on results of their own activities through sustainability reports, these reports create mutual benefit by creating a more transparent and reliable enterprise perception on stakeholder groups. Sustainability reports have gradually become instruments frequently referred in studies as resources as they are practical as well as they provide the most comprehensive and comparative data on sustainability related practices of enterprises (Şahin \& Çankaya, 2018; Dinler, 2018; Duran, 2018; Kolk, 2004).

Purposive sampling has been used as the sampling method. Although, the exact number of sustainability reports issued in Turkey is not known, the sample of this study consists of 103 enterprises issuing reports which were listed in www.kurumsalsurdurulebilirlik.com portal and Borsa Istanbul (BIST) Sustainability Index as of 10 November 2017. However, as it was determined that 6 of these reports were activity or financial reports and 4 were not technically appropriate for an examination, 93 reports have been examined within the scope of the study.

Kurumsalsurdurulebilirlik.com portal has been selected as the reference consisting the sample of this study as it is the most comprehensive and detailed source where sustainability reports within the context of Turkey are collected. This portal was established by Kiymet-i Harbiye Management and Consultancy Firm and it has been a regional data partner with Global Reporting Initiative (GRI) since 2012. (http://www.kurumsalsurdurulebilirlik.com/ tr-tr/anasayfa.aspx\#). BIST Sustainability Index subject enterprises to an assessment based on international sustainability criteria for improving the understanding, knowledge and practices in Turkey, especially the BIST companies and determining the companies with high corporate sustainability performance levels. BIST has signed a cooperation agreement with an independent research firm, Ethical Investment Research Services Limited (EIRIS) to conduct that assessment. (http://www.borsaistanbul.com/endeksler/bist-pay-endeksleri/ surdurulebilirlik -endeksi).

The elements in GRI G4 Standard as it is the most current standard for selecting the codes and establishing the themes to be used in the study and Sustainable HRM literature have 
been used. As coding is important for reliability of the study in qualitative studies, the percent of agreement index has been used for calculating coding reliability. The percent of agreement calculated through the formula has been found as 0.89 . It is expected that a percentage of agreement is higher than $70 \%$ in order to determine reliability of a study. As the percentage of agreement has been found higher than $70 \%$, it has been decided that the coding is reliable (Tavşancıl \& Aslan, 2001).

Maxqda software has been used for analyzing the report related data. The codes used out of the theme's context have been eliminated by individually reading the codes presented in spreadsheets produced by Maxqda where they were used in sustainability reports.

\subsubsection{Results and Discussion of the First Phase}

The themes and codes determined after examining the sustainability reports and the findings on how frequently they are repeated in the reports are presented in Table 1.

Table 1: Frequencies of the Codes and Themes

\begin{tabular}{|c|c|c|c|}
\hline Theme & Codes & $\mathbf{n}$ & Total \\
\hline \multirow{5}{*}{$\begin{array}{l}\text { Occupational } \\
\text { Health and Safety }\end{array}$} & Zero accident & 7 & \multirow{5}{*}{468} \\
\hline & Safety working & 22 & \\
\hline & Human rights & 120 & \\
\hline & Work health & 203 & \\
\hline & Job security & 116 & \\
\hline \multirow{2}{*}{$\begin{array}{l}\text { Talent } \\
\text { Management }\end{array}$} & Competence & 268 & \multirow{2}{*}{360} \\
\hline & Competence management & 92 & \\
\hline \multirow{7}{*}{$\begin{array}{l}\text { Diversity } \\
\text { Management }\end{array}$} & Equal opportunity & 212 & \multirow{7}{*}{358} \\
\hline & Gender distribution & 18 & \\
\hline & Women employment & 25 & \\
\hline & Fair working environment & 6 & \\
\hline & Equal job & 22 & \\
\hline & Social diversity/gender equality & 57 & \\
\hline & Women's empowerment & 18 & \\
\hline \multirow{7}{*}{$\begin{array}{l}\text { Performance } \\
\text { Assessment }\end{array}$} & Transparent evaluation /pricing & 10 & \multirow{7}{*}{349} \\
\hline & Self-assessment & 6 & \\
\hline & Fairy evaluation /pricing & 33 & \\
\hline & Award & 171 & \\
\hline & Appreciation & 60 & \\
\hline & Equal pay for equal work & 69 & \\
\hline & Performance assessment & 79 & \\
\hline
\end{tabular}




\section{Table 1 continued}

\begin{tabular}{|c|c|c|c|}
\hline \multirow{4}{*}{$\begin{array}{l}\text { Employee Satisfaction } \\
\text { and Commitment }\end{array}$} & Employee participation & 21 & \multirow{4}{*}{263} \\
\hline & Employee engagement & 89 & \\
\hline & Clubs & 66 & \\
\hline & Motivation & 87 & \\
\hline \multirow{6}{*}{ Well-being } & Employee happiness & 11 & \multirow{6}{*}{260} \\
\hline & Support for sports activities & 123 & \\
\hline & Pension & 57 & \\
\hline & Individual pension & 21 & \\
\hline & Quality of life & 7 & \\
\hline & Social events & 41 & \\
\hline \multirow{8}{*}{$\begin{array}{l}\text { Continuous } \\
\text { Development and } \\
\text { Training }\end{array}$} & Invest in human being & 3 & \multirow{8}{*}{235} \\
\hline & Employee development & 19 & \\
\hline & Individual development & 28 & \\
\hline & Education hour & 48 & \\
\hline & Training needs analyze & 2 & \\
\hline & Planning of education & 10 & \\
\hline & Orientation & 95 & \\
\hline & Vocational training & 27 & \\
\hline \multirow{2}{*}{ Voluntariness } & Volunteers & 140 & \multirow{2}{*}{142} \\
\hline & Social benefit & 2 & \\
\hline \multirow{6}{*}{$\begin{array}{l}\text { Work-Life } \\
\text { Balance }\end{array}$} & Flexible working & 22 & \multirow{6}{*}{94} \\
\hline & Maternity leave & 51 & \\
\hline & Absenteeism rate & 13 & \\
\hline & Work-life balance & 1 & \\
\hline & Part-time working & 2 & \\
\hline & Breastfeeding rooms & 5 & \\
\hline \multirow{5}{*}{ Career Management } & Career management & 25 & \multirow{5}{*}{89} \\
\hline & Career planning & 30 & \\
\hline & Career maps & 6 & \\
\hline & Needs of development & 21 & \\
\hline & Internal assignment & 7 & \\
\hline
\end{tabular}


Table 1 continued

\begin{tabular}{|c|c|c|c|}
\hline \multirow{3}{*}{ Green Applications } & E-learning & 21 & \multirow{3}{*}{71} \\
\hline & E-education & 27 & \\
\hline & Transportation service & 23 & \\
\hline \multirow{11}{*}{ Additional Benefits } & Cash indemnity & 1 & \multirow{11}{*}{70} \\
\hline & Road fee & 1 & \\
\hline & Clothing allowance & 18 & \\
\hline & Immigration compensation & 1 & \\
\hline & Travel enumeration & 1 & \\
\hline & Goods transfer allowance & 1 & \\
\hline & Accident compensation & 1 & \\
\hline & Natural disaster allowance & 2 & \\
\hline & Private health/life insurance & 42 & \\
\hline & Food allowance & 1 & \\
\hline & Language compensation & 1 & \\
\hline \multirow{3}{*}{$\begin{array}{l}\text { In-house } \\
\text { communication }\end{array}$} & Suggestion system & 29 & \multirow{3}{*}{62} \\
\hline & In-house communication & 13 & \\
\hline & Communication channels & 20 & \\
\hline \multirow{2}{*}{ Working Conditions } & Working conditions & 41 & \multirow{2}{*}{47} \\
\hline & Decent work & 6 & \\
\hline
\end{tabular}

Enterprises issue their sustainability reports in accordance with the provisions of the GRI Standards. Therefore, considering the prominent themes, it can be said that "the occupational health and safety" and "managing diversity (diversity and equal opportunity)" themes are frequently repeated both for compliance with the GRI Standards and as being the issues considered important by enterprises for their sustainability efforts.

GRI Standards do not directly contain "the talent management" topic. However, particularly "competence" code and "talent management" themes are frequently included in the examined sustainability reports. This can be interpreted as sustainability efforts of enterprises are associated with talent management activities of HR.

In accordance with the GRI Standards, it draws attention that non-obligatory issues such as "satisfaction and loyalty of employees", "subjective well-being", "voluntary participation", "work-life balance", "career management", "green practices" and etc. are frequently used in sustainability reports. This is considered as at least a part of enterprises issuing sustainability reports follow the sustainability literature in the world and transfer studies on that issue to their enterprises.

Based on the findings, it can be said that the practices such as "occupational health and safety", "talent management", "diversity management", "performance assessment", 


\begin{abstract}
"satisfaction and loyalty of employees", "subjective well-being", "continuous development and training", "voluntary participation of employees in social activities", "work-life balance", "career management", "green practices", "additional benefits", "in-house communication" and "working conditions" are the HRM practices supporting sustainability efforts of enterprises.
\end{abstract}

\title{
2.2.2. Second Phase: Expert Opinion about Sustainable Human Resources Management
}

\subsubsection{Method for the Second Phase}

In the second phase of the study, it was aimed to get opinions of experts on conceptual expression and dimensions of Sustainable HRM and come to an understanding through these opinions. In addition, the items to be included in the questionnaire to be developed for defining the dimensions of Sustainable HRM were questioned. The findings from the previous phases were used for determining the items to be included in the Sustainable HRM questionnaire.

The Delphi technique was selected for this phase as it is used as an agreement tool. By means of this technique, it is ensured that people with different perspectives on an issue express their opinions systematically without confronting and influencing each other. By means of Delphi technique, it is not necessary to get experts at different locations together at the same time (Rowe \& Wright, 1999). Although, a certain number of participants is not provided in the Delphi technique, this number is closely related with the issue to be discussed (Bazzani \& Canavari, 2013). According to Şahin (2001), the groups can have at least 7 participants, ideal group size is 10-20 experts. In Delphi technique, it is unnecessary that the number of experts is a statistically representative sample, because, representability of this technique is assessed based on quality of the panel of these participant experts rather than their number (Power, 2003).

In the study, purposive sampling method was used and the participants were selected from two separate groups as the academicians with specialties in sustainability, human resources management, administration, organization and the HR officers from enterprises with specialty in sustainability practices. Arçelik, Alarko Holding, Vodafone, Dem Medicine, Vestel, Yaşar Holding Company, Hürriyet Newspaper, Sustainability management consultants and company owners has been involved among the participating institutions. The universities where academics work are; Marmara University, Koç University, TOBB Economics and Technical University, Yıldız Technical University, Ege University, Kocaeli University, Dokuz Eylül University, Namık Kemal University, Adnan Menderes University, Afyon Kocatepe University. Details related with the participants are given in Table 2.

Table 2: Distribution of the Participants in Delphi Panel Based on Their Titles

\begin{tabular}{lclc}
\hline & \multicolumn{2}{c}{ Academicians } \\
\hline Director of HR & 3 & Professor Doctor & 4 \\
\hline HR Manager & 2 & Associate Professor & 5 \\
\hline HR Expert & 3 & \multirow{2}{*}{ Assistant Professor } & 2 \\
\cline { 1 - 2 } Sustainability (HR) Consultant & 3 & & $\mathbf{1 1}$ \\
\hline Total & $\mathbf{1 1}$ & & \\
\hline
\end{tabular}


Delphi study was completed in three turns. Obtained data was subjected to statistical analyses to compute descriptive analysis, median, first quarter, third quarter and range values.

In the $1^{\text {st }}$ Delphi turn, an item pool was established through the national and international literature review and content analysis findings from the HRM related parts of sustainability reports. While, establishing the item pool, interviews on places of questionnaire items, verbiage, context, understandability and etc. issues were held with eight academicians, expert on HRM and digital methods. Then, the item pool of 26 items was put into its final form. This item pool is presented in Table 3 .

\section{Table 3: Item Pool used in the First Delphi Turn}

\begin{tabular}{ll}
\hline Items & Resources
\end{tabular}

1. In the job application process, instead of applying on paper, electronic and technological methods should be Jepsen \& Grob, 2015:166-168 presented.

2. The use of mass transportation should be encouraged on the way to the job interview.

Jepsen \& Grob, 2015:166-168

3. Instead of face-to-face interviews, the teleconference method should be presented as an alternative in the job Jepsen \& Grob, 2015:166-168 interview.

4. During employee selection, it should be questioned that if employees sensitive or not on environmental issues.

Freitas et al., 2012:152

5. Educational materials can be accessed electronically to reduce paper consumption.

Masri \& Jaaron, 2017:487

6. Job interview hours are appropriate for the candidate or offer flexibility in timing for candidate.

Jepsen \& Grob, 2015:166-168

7. Flexible working hours (flexible working hours, part-

Rompa, 2011:97-110; time working hours, home office, tele-working) should be applied.

Mariappanadar \& Kramar, 2014:212; Zaugg et al., 2001:19; Konrad et al., 2016:9

8. Employees should be trained on sustainability.

Freitas et al., 2012:152;

Masri \& Jaaron, 2017:487

Construction Materials

Industrialist Association,

9. Employees should be given regular trainings on their the Evaluation Report for jobs.

Sustainability Awareness in

Turkish Construction Sector, 2012 (www.imsad.org.tr) 


\section{Table 3 continued}

10. Employees should be given autonomy in matters such as participation in decision-making, working order and www.imsad.org.tr setting of work objectives.

11. Employees should be offered opportunities to improve their careers.

www.imsad.org.tr

12. Non-business volunteer studies should be considered in performance evaluation.

Freitas et al., 2012:152

13. Material and non-material awards (salaried leave, leave, gifts, cash, points, promotion) should be given

Masri \& Jaaron, 2017:487; to employees due to their voluntary services that Jensen et al., 2013:1719 contribute to the environment or society.

14. Long-term employment of employees at all levels should be emphasis placed on.

Developed by the researcher.

15. Employees should benefit from basic rights (health insurance, transportation support, food aid, child

Demo et al., 2012:404-405 allowance, etc.

16. Employees should be provided with side benefits (such as private health insurance, life insurance, kindergarten, financial support for sports-related actions.

Rompa, 2011:97-110; Freitas et al., 2012:152; Demo et al., 2012:404-405

17. Employees should be given the cost of public transport or other "green" transportation option's costs.

18. Healthy food should be served in the restaurant of enterprises.

Rompa, 2011:97-110

Rompa, 2011:97-110; Freitas et al., 2012:152; Demo et al., 2012:404-405

19. During the working hours, fun areas such as television, Rompa, 2011:97-110; Freitas internet, games and recreation centers should be provided.

et al., 2012:152; Demo et al., 2012:404-405

20. Work areas should be physically and psychologically comfortable and suitable for work.

Rompa, 2011:97-110; Freitas et al., 2012:152; Demo et al., 2012: 404-405

21. Employees occupational safety should be ensured. www.imsad.org.tr

22. Employee work-life balance (career and family harmony) should be ensured.

www.imsad.org.tr

23. Employees' health and quality of life should be maintained.

www.imsad.org.tr

24. Employees should be encouraged to take part in social responsibility projects.

Freitas et al., 2012:152 


\section{Table 3 continued}

25. Elderly employees, female employees, disabled employees and employees of different nationalities should be employed at an adequate level.

Jepsen \& Grob, 2015:166-168;

Freitas et al., 2012:152.

It was inspired by the speech

26. Efforts should be made to make it easier for employees to adapt to life after retirement.

of Nursel Ölmez Ateş (Ford

Otosan HR Director) in

the $14^{\text {th }}$ Aegean Human

Management Summit)

In the first delphi turn, it was requested from the participants to evaluate whether the items in this pool were appropriate to be included in the Sustainable HRM questionnaire planned to be developed (yes-appropriate/no-inappropriate). Furthermore, in this turn, openended questions were included for the participants to identify Sustainable HRM through their own words and indicate their opinions.

In accordance with the recommendations from the first Delphi turn, new items were added in the items pool and expressions of existing ones were changed. Thus, the second Delphi turn was started and the renewed questionnaire was presented to the participants for reevaluation. In the third Delphi turn, the items in the second Delphi turn were sent to the participants without changing. The purpose of the third turn is to allow the participants to reevaluate their opinions and come to an agreement between them.

\subsubsection{Results and Discussion of the Second Phase}

Upon the recommendations and criticisms of participants presented in the first Delphi turn, 16 of 26 items were changed and a new item to represent talent management related activities was added. As a result, number of items at the end of the first Delphi turn increased from 26 to 29 .

The opinions of participants on the options to be included in the dimensions of Sustainable HRM are presented in Table 4.

Table 4: Dimensions of Sustainable Human Resource Management

\begin{tabular}{lcc}
\hline Dimensions of Sustainable HRM & $\begin{array}{c}\text { Academicians } \\
(\boldsymbol{\%})\end{array}$ & $\begin{array}{c}\text { HRM Experts } \\
(\boldsymbol{\%})\end{array}$ \\
\hline Green HRM & 0.72 & 0.63 \\
\hline Participation in social projects as a volunteer & 0.90 & 0.54 \\
\hline Flexible working arrangements & 0.90 & 0.54 \\
\hline Human rights, health and safety practices & 0.72 & 0.72 \\
\hline Diversity management & 0.100 & 0.72 \\
\hline Work-life balance & 0.100 & 0.81 \\
\hline
\end{tabular}


In the final part of the first Delphi turn, it was requested from the participants to define Sustainable HRM through their own terms. Answers to this question were examined through descriptive analysis method. From statements of the participants, the prominent concepts in defining Sustainable HRM were summarized under 9 topics: "Environmental and social sensitivity/awareness", "ensuring subjective well-being of human resources", "diversity management and increasing diversity", "ensuring work-life balance", "long-term employment of human resources", "value-chain approach", "transmissibility to future generations", "mutual interest at employer and human resources side", "talent management".

It is understood that academicians and HRM experts address Sustainable HRM in the frame of a value-chain approach, welfare and commitment of several stakeholders from human resources to suppliers, financial environment to social and ecological environment is observed in this chain and HRM is an important trigger of this process.

An impression is formed where the restrictive perspective that the decisions and actions related with HRM should be integrated with executive decisions and actions which only determines the strategies of an organization leaves its place to a holistic perspective with a more transparent and flexible structure to cover the stakeholders in great circle.

The essential difference between the answers of academicians and HRM experts is while academicians consider "enterprise" as the active side for regulating, positioning and developing Sustainable HRM, HR experts tend to consider "human resources" as that active side.

In the light of this information, Sustainable HRM can be identified as a management approach aiming the HRM practices preventing exhaustion of employees, raising awareness of them on greater circle and supporting them to provide their contribution not only for their enterprise but also for the world they live in to create positive value on society, ecology and economy through value chain approach.

As, participant opinions on item contents were obtained in the first Delphi turn, no change was done on contents of the items during the second and third Delphi turns. The purpose of the second and third Delphi turns was to reach an agreement between the participants. The findings of the second and third Delphi turns are presented in Table 5.

Table 5: Statistics of the Second and Third Delphi Turns

\begin{tabular}{ccccccccc}
\hline Item & \multicolumn{3}{c}{ II. Delphi Panel } & & \multicolumn{3}{c}{ III. Delphi Panel } \\
\cline { 2 - 9 } & $\begin{array}{c}\text { First } \\
\text { Quarter }\end{array}$ & Median & $\begin{array}{c}\text { Third } \\
\text { Quarter }\end{array}$ & $\begin{array}{c}\text { Range } \\
(\mathbf{r})\end{array}$ & $\begin{array}{c}\text { First } \\
\text { Quarter }\end{array}$ & Median & $\begin{array}{c}\text { Third } \\
\text { Quarter }\end{array}$ & $\begin{array}{c}\text { Range } \\
(\mathbf{r})\end{array}$ \\
\hline $\mathbf{1}$ & 5.00 & 6.50 & 7.00 & 2.00 & 6.00 & 7.00 & 7.00 & 1.00 \\
\hline $\mathbf{2}$ & 6.00 & 7.00 & 7.00 & 1.00 & 6.00 & 6.50 & 7.00 & 1.00 \\
\hline $\mathbf{3}$ & 5.00 & 6.00 & 7.00 & 2.00 & 5.00 & 6.50 & 7.00 & 2.00 \\
\hline $\mathbf{4}$ & 5.00 & 5.50 & 7.00 & 2.00 & 5.00 & 6.00 & 7.00 & 2.00 \\
\hline $\mathbf{5}$ & 5.00 & 6.00 & 7.00 & 2.00 & 5.75 & 6.00 & 7.00 & 1.25 \\
\hline $\mathbf{6}$ & 6.00 & 7.00 & 7.00 & 1.00 & 7.00 & 7.00 & 7.00 & 0.00 \\
\hline
\end{tabular}


Table 5 continued

\begin{tabular}{ccccccccc}
\hline $\mathbf{7}$ & 4.00 & 6.00 & 7.00 & 3.00 & 5.00 & 6.00 & 7.00 & 2.00 \\
\hline $\mathbf{8}$ & 5.75 & 6.00 & 7.00 & 1.25 & 6.00 & 7.00 & 7.00 & 1.00 \\
\hline $\mathbf{9}$ & 6.00 & 7.00 & 7.00 & 1.00 & 6.75 & 7.00 & 7.00 & 0.25 \\
\hline $\mathbf{1 0}$ & 6.00 & 7.00 & 7.00 & 1.00 & 6.00 & 7.00 & 7.00 & 1.00 \\
\hline $\mathbf{1 1}$ & 5.00 & 6.00 & 6.25 & 1.25 & 6.00 & 6.00 & 6.25 & 0.25 \\
\hline $\mathbf{1 2}$ & 6.75 & 7.00 & 7.00 & 0.25 & 7.00 & 7.00 & 7.00 & 0.00 \\
\hline $\mathbf{1 3}$ & 4.00 & 6.50 & 7.00 & 3.00 & 4.00 & 6.00 & 7.00 & 3.00 \\
\hline $\mathbf{1 4}$ & 5.75 & 7.00 & 7.00 & 1.25 & 6.00 & 7.00 & 7.00 & 1.00 \\
\hline $\mathbf{1 5}$ & 4.75 & 7.00 & 7.00 & 2.25 & 5.00 & 6.50 & 7.00 & 2.00 \\
\hline $\mathbf{1 6}$ & 5.00 & 6.50 & 7.00 & 2.00 & 5.00 & 6.50 & 7.00 & 2.00 \\
\hline $\mathbf{1 7}$ & 6.00 & 7.00 & 7.00 & 1.00 & 6.00 & 6.00 & 7.00 & 1.00 \\
\hline $\mathbf{1 8}$ & 6.00 & 7.00 & 7.00 & 1.00 & 6.00 & 6.00 & 7.00 & 1.00 \\
\hline $\mathbf{1 9}$ & 5.75 & 7.00 & 7.00 & 1.25 & 5.75 & 7.00 & 7.00 & 1.25 \\
\hline $\mathbf{2 0}$ & 7.00 & 7.00 & 7.00 & 0.00 & 7.00 & 7.00 & 7.00 & 0.00 \\
\hline $\mathbf{2 1}$ & 6.00 & 7.00 & 7.00 & 1.00 & 6.00 & 7.00 & 7.00 & 1.00 \\
\hline $\mathbf{2 2}$ & 7.00 & 7.00 & 7.00 & 0.00 & 7.00 & 7.00 & 7.00 & 0.00 \\
\hline $\mathbf{2 3}$ & 7.00 & 7.00 & 7.00 & 0.00 & 7.00 & 7.00 & 7.00 & 0.00 \\
\hline $\mathbf{2 4}$ & 7.00 & 7.00 & 7.00 & 0.00 & 7.00 & 7.00 & 7.00 & 0.00 \\
\hline $\mathbf{2 5}$ & 6.75 & 7.00 & 7.00 & 0.25 & 7.00 & 7.00 & 7.00 & 0.00 \\
\hline $\mathbf{2 6}$ & 6.00 & 7.00 & 7.00 & 1.00 & 6.75 & 7.00 & 7.00 & 0.25 \\
\hline $\mathbf{2 7}$ & 6.00 & 7.00 & 7.00 & 1.00 & 6.00 & 7.00 & 7.00 & 1.00 \\
\hline $\mathbf{2 8}$ & 7.00 & 7.00 & 7.00 & 0.00 & 7.00 & 7.00 & 7.00 & 0.00 \\
\hline $\mathbf{2 9}$ & 5.75 & 7.00 & 7.00 & 1.25 & 6.00 & 7.00 & 7.00 & 1.00 \\
\hline & & & & & & & & \\
\hline $\mathbf{1 4}$ & & & & \\
\hline
\end{tabular}

While, the high range ( $\mathrm{r}$ value) represents the difference of opinion between the participants, low range value indicates the agreement between them (Şahin, 2001). According to the findings in Table 5, the agreement between participants has increased in the third Delphi turn. However, as the $r$ value of the item was $(r=3.00)$, it was decided to remove the 13 th item from the form.

The item pool after the Delphi technique related studies was presented to the opinions of three experts specialized in Turkish language and management who were not consulted before. In accordance with the recommendations upon these analyses, it was considered that the expressions in the 3rd and 19th items repeated each other ("Use of mass transportation, personnel service and bicycle should be encouraged for accessing the workplace", "Mass transportation expenses or other 'green' means of access of personnel should be compensated"), it was decided to remove the 19th item from the form. 
As a result, while the number of items to be included in the Sustainable HRM questionnaire was 26 in the first Delphi turn, it was increased to 29 as a result of the recommendations from participants. As a result of the analyses conducted through the data obtained in the third Delphi turn, the number of items was determined as 27. Moreover, after presenting a conceptual frame for dimensions and conceptual expression of Sustainable HRM, the following phase of the study was initiated.

\subsubsection{Third Phase: A Quantitative Study on Sustainable Human Resources Management and Developing a Sustainable Human Resource Management Questionnaire}

\subsubsection{The Method for the Third Phase}

In the third phase of the study, the perception for importance of the HRM practices was questioned in terms Sustainable HRM through the Sustainable HRM questionnaire prepared by using the findings from previous phases of the study. In addition, it was intended to determine whether there are any Sustainable HRM practices and strategic level of sustainability in enterprises and the driving and facilitating forces of sustainability practices.

Population of the study consists of the HRM experts of enterprises issuing sustainability reports and the ones working in the enterprises included in the 2017 BIST Sustainability Index. 400 HRM experts working in 113 enterprises determined in this context were sent the questionnaire and $143 \mathrm{HRM}$ experts responded. However, 12 forms were not proper for an assessment so the analyses were done by using the answers from 131 forms. SPSS 23.0 package software was used for analyzing the obtained data.

As a result of the availability and reliability analyses of the Sustainable HRM questionnaire form, the Cronbach Alpha factor was found as 0.92. According to the findings of the explanatory factor analysis, KMO value was calculated as $0.78 ; \mathrm{X}^{2}=1390.332$ at $\mathrm{p}=0.000$ significance level. "Varimax" rotation technique was applied for determining the factors where the items were laden. Factor lower limit was determined as 0.40. (Malthouse, 2001; Büyüköztürk, 2002)

As a result of distribution of item factor loads, it was determined that the 14th item was laden onto the second and third factors and the load value of these factors was lower than 0.10 , it was excluded from the analysis. As a result of the repeated factor analysis, it was determined that the 15th item was added in two dimensions with its factor loads lower than 0.30 and it was decided to exclude it from the analysis. As a result of the factor analysis repeated after excluding these two items, the KMO value was computed as 0.76 and $\mathrm{X}^{2}=1242.082 \mathrm{at} \mathrm{p}=0.000$ significance level, so it was determined that the data preserved its compliance with the factor analysis.

After, excluding these two items from the assessment tool, it was observed that the presented total variance increased from 56.86 to 57.85 . The load distributions and presented variance values of the remaining 25 items are presented in Table 6. 
Table 6: Findings of the Explanatory Factor Analysis

\begin{tabular}{|c|c|c|c|c|c|c|c|}
\hline & \multirow{2}{*}{$\begin{array}{c}\text { Items } \\
1\end{array}$} & \multicolumn{4}{|c|}{ Factor Load } & \multirow{2}{*}{$\begin{array}{l}\mathrm{V} \\
(\%)\end{array}$} & \multirow{2}{*}{$\begin{array}{l}\text { TV } \\
(\%)\end{array}$} \\
\hline & & 2 & 3 & 4 & 5 & & \\
\hline \multirow{11}{*}{ 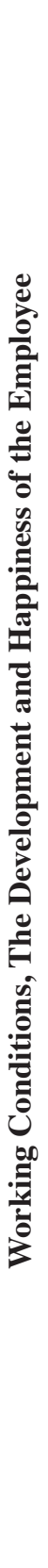 } & $\begin{array}{l}\text { 9. Providing sustainability trainings } \\
\text { to employees }\end{array}$ & & & & .509 & \multirow{11}{*}{$\begin{array}{l}\infty \\
\dot{a}\end{array}$} & \multirow{11}{*}{$\begin{array}{l}\ddot{\infty} \\
\dot{a}\end{array}$} \\
\hline & $\begin{array}{l}\text { 10. Providing regular in-service } \\
\text { trainings to employees }\end{array}$ & & & & .688 & & \\
\hline & $\begin{array}{l}\text { 11. Providing opportunity to } \\
\text { employees for decision-making } \\
\text { (work order, setting goals, etc. }\end{array}$ & & & & .708 & & \\
\hline & $\begin{array}{l}\text { 12. Providing opportunities to } \\
\text { employees for improve their } \\
\text { careers. }\end{array}$ & & & & .638 & & \\
\hline & $\begin{array}{l}\text { 13. Encouraging the participation of } \\
\text { employees in social responsibility } \\
\text { projects. }\end{array}$ & & & & .552 & & \\
\hline & $\begin{array}{l}\text { 18. Providing healthy food in the } \\
\text { restaurant of enterprises. }\end{array}$ & & & & .635 & & \\
\hline & $\begin{array}{l}\text { 19. There are areas in the institution } \\
\text { that will allow the employees to } \\
\text { relax and have a pleasant time. }\end{array}$ & & & & .487 & & \\
\hline & $\begin{array}{l}\text { 20. Appropriateness of workplaces } \\
\text { for physically and psychologically } \\
\text { comfortable work activities }\end{array}$ & & & & .625 & & \\
\hline & $\begin{array}{l}\text { 21. Taking necessary precaution for } \\
\text { the job security of employees. }\end{array}$ & & & & 640 & & \\
\hline & $\begin{array}{l}\text { 22. Giving importance to the health } \\
\text { and quality of life of employees. }\end{array}$ & & & & .623 & & \\
\hline & $\begin{array}{l}\text { 24. Practices to make employees } \\
\text { happy (social / sporting activities, } \\
\text { clubs, free invitations for cultural } \\
\text { events, surprise refreshments, } \\
\text { health counseling line etc.) }\end{array}$ & & & & .484 & & \\
\hline
\end{tabular}




\section{Table 6 continued}

23. Giving importance to the work-life balance (career and family unity

harmony) of employees.

25. Carrying out studies that will make

it easier for employees to adapt to

life of after retirement.

26. Conducting employment

policies in accordance with the

management of diversity (elderly,

women, disabled and different

citizens, etc.

27. Conducting the employment

policies in accordance with

talent management (recruiting,

developing and maintaining

talented candidates)

1. Inclusion of criteria related to environmental sensitivity in job

descriptions

3. Encouraging the use of mass transportation, personnel service, bicycle etc., while transportation to the business.

5. Questioning the sensitivity on environmental issues in the

selection of employees 


\section{Table 6 continued}

7. Determining job interview hours the flexibility of candidate's choose

8. Flexible working hours (flexible working, part-time working, home

office, tele-working etc.)

16. Benefit from basic rights of temporary and part-time employees' health insurance, transportation support, food aid, child allowance etc.

17. Provision of side benefits (private health insurance, life insurance, nursery, financial support of sport related actions etc.) to temporary and part-time employees

2. Digitalization of job application process.

4. Submission of teleconferencing as an alternative method for job interviews.

6. Access to educational materials from digital media.

It is seen from Table 6 that Sustainable HRM questionnaire is gathered in five dimensions. These dimensions are named as "Working Conditions, Development and Happiness of Employee", "Sustainable Employment Policies", "Environmental Consciousness", "Flexibility Practices" and "Paperless-Digital Processes". In addition, the Sustainable HRM questionnaire form explains $57.85 \%$ of the total variance. It was observed that the determined dimensions respectively explain $18.666 \%, 12.423 \%, 9.089 \%, 9.039 \%$ and $8.636 \%$ of the variance.

Correspondence of the items included in the analysis to the scale was questioned through item analysis. 
Table 7: Item-Total Correlation of the Sustainable HRM Questionnaire Form

\begin{tabular}{|c|c|c|c|c|c|c|c|c|}
\hline 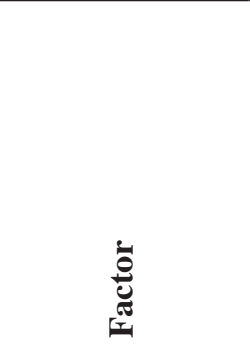 & $\stackrel{\varrho}{\text { E }}$ & $=$ & $1 x$ & 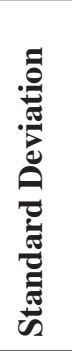 & 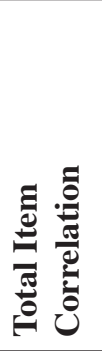 & 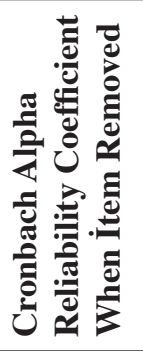 & 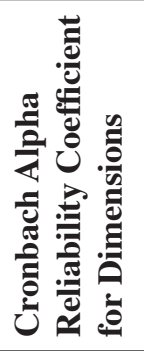 & 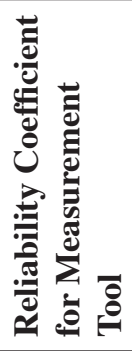 \\
\hline \multirow{11}{*}{$\begin{array}{c}\text { Working } \\
\text { Conditions, } \\
\text { The } \\
\text { Development } \\
\text { and Happiness } \\
\text { of the } \\
\text { Employee }\end{array}$} & I9 & 131 & 4.31 & .72 & .42 & .86 & \multirow{11}{*}{.82} & \multirow{25}{*}{.87} \\
\hline & $\mathrm{I} 10$ & 131 & 4.33 & .67 & .47 & .86 & & \\
\hline & I11 & 131 & 4.26 & .73 & .41 & .87 & & \\
\hline & $\mathrm{I} 12$ & 131 & 4.42 & .73 & .59 & .86 & & \\
\hline & I13 & 131 & 4.33 & .73 & .55 & .86 & & \\
\hline & $\mathrm{I} 18$ & 131 & 4.42 & .75 & .40 & .87 & & \\
\hline & I19 & 131 & 4.29 & .75 & .53 & .86 & & \\
\hline & I20 & 131 & 4.42 & .70 & .53 & .86 & & \\
\hline & $\mathrm{I} 21$ & 131 & 4.56 & .73 & .30 & .87 & & \\
\hline & $\mathrm{I} 22$ & 131 & 4.49 & .74 & .42 & .87 & & \\
\hline & $\mathrm{I} 24$ & 131 & 4.33 & .75 & .49 & .86 & & \\
\hline \multirow{4}{*}{$\begin{array}{c}\text { Sustainable } \\
\text { Employment } \\
\text { Policies }\end{array}$} & $\mathrm{I} 23$ & 131 & 4.40 & .76 & .43 & .87 & \multirow{4}{*}{.61} & \\
\hline & $\mathrm{I} 25$ & 131 & 3.97 & .90 & .47 & .86 & & \\
\hline & $\mathrm{I} 26$ & 131 & 4.24 & .77 & .55 & .86 & & \\
\hline & $\mathrm{I} 27$ & 131 & 4.34 & .80 & .47 & .87 & & \\
\hline \multirow{3}{*}{$\begin{array}{l}\text { Environmental } \\
\text { Consciousness }\end{array}$} & I1 & 131 & 4.00 & .84 & .33 & .87 & \multirow{3}{*}{.60} & \\
\hline & I3 & 131 & 3.92 & .94 & .29 & .87 & & \\
\hline & I5 & 131 & 3.98 & .86 & .30 & .87 & & \\
\hline \multirow{4}{*}{$\begin{array}{c}\text { Flexibility } \\
\text { Applications }\end{array}$} & I7 & 131 & 3.98 & .88 & .34 & .87 & \multirow{4}{*}{.71} & \\
\hline & I8 & 131 & 4.14 & .93 & .45 & .87 & & \\
\hline & I16 & 131 & 4.32 & .78 & .63 & .86 & & \\
\hline & I17 & 131 & 4.20 & .86 & .56 & .86 & & \\
\hline \multirow{3}{*}{$\begin{array}{c}\text { Paperless- } \\
\text { Digital } \\
\text { Processes }\end{array}$} & $\mathrm{I} 2$ & 131 & 4.32 & .74 & .29 & .87 & \multirow{3}{*}{.56} & \\
\hline & I4 & 131 & 4.09 & .76 & .26 & .87 & & \\
\hline & I6 & 131 & 4.32 & .69 & .41 & .87 & & \\
\hline
\end{tabular}

Item-total test correlations for each item is higher than $(r=.25)$. This indicates that there is not any item decreasing reliability and the items are corresponding to the scale. The Cronbach Alpha factor related with overall assessment tool is 0.87 . 


\subsubsection{Results and Discussion of the Third Phase}

The findings on the perception of significance level of the items in the Sustainable HRM questionnaire form for defining Sustainable HRM are presented in Table 8.

Table 8: Findings on Perception of Significance Level of the Items Defining Sustainable HRM

\begin{tabular}{|c|c|c|c|c|c|c|c|c|c|c|c|c|c|c|}
\hline \multirow{2}{*}{\multicolumn{2}{|c|}{$\underset{\mathbf{n}}{\text { Items }}$}} & \multicolumn{2}{|c|}{1} & \multicolumn{2}{|c|}{2} & \multicolumn{2}{|c|}{3} & \multicolumn{2}{|c|}{4} & \multicolumn{2}{|c|}{5} & \multirow{2}{*}{$\mathbf{x}^{-}$} & \multirow{2}{*}{ Ss } & \multirow{2}{*}{ '气 } \\
\hline & & $\%$ & $\mathbf{n}$ & $\%$ & $\mathbf{n}$ & $\%$ & n & $\%$ & $\mathbf{n}$ & $\%$ & & & & \\
\hline \multirow{11}{*}{$\mathbf{I}$} & I9 & 1 & 0.4 & 6 & 2.2 & 17 & 6.1 & 134 & 48.4 & 118 & 42.6 & 4.31 & .71 & \multirow{11}{*}{$\stackrel{\infty}{\stackrel{\infty}{+}}$} \\
\hline & $\mathrm{I} 10$ & - & - & 2 & 0.7 & 25 & 0.9 & 129 & 46.6 & 121 & 43.7 & 4.33 & .66 & \\
\hline & I11 & 1 & 0.4 & 5 & 1.8 & 26 & 9.4 & 133 & 48.0 & 112 & 40.4 & 4.26 & .73 & \\
\hline & I12 & 1 & 0.4 & 5 & 1.8 & 19 & 6.9 & 103 & 37.2 & 149 & 53.8 & 4.42 & .73 & \\
\hline & I13 & 1 & 0.4 & 3 & 1.1 & 27 & 9.7 & 118 & 42.6 & 127 & 45.8 & 4.33 & .72 & \\
\hline & I18 & 1 & 0.4 & 4 & 1.4 & 25 & 9.0 & 94 & 33.9 & 151 & 54.5 & 4.42 & .74 & \\
\hline & I19 & 2 & 0.7 & 3 & 1.1 & 29 & 10.5 & 122 & 44.0 & 121 & 43.7 & 4.29 & .75 & \\
\hline & I 20 & 1 & 0.4 & 1 & 0.4 & 24 & 8.7 & 108 & 37.9 & 146 & 52.7 & 4.42 & .69 & \\
\hline & $\mathrm{I} 21$ & 1 & 0.4 & 5 & 1.8 & 19 & 6.9 & 65 & 23.5 & 187 & 67.5 & 4.56 & .73 & \\
\hline & $\mathrm{I} 22$ & 2 & 0.7 & 4 & 1.4 & 16 & 5.8 & 90 & 32.5 & 165 & 59.6 & 4.49 & .73 & \\
\hline & I24 & 2 & 0.7 & 2 & 0.7 & 29 & 10.5 & 113 & 40.8 & 131 & 47.3 & 4.33 & .75 & \\
\hline \multirow{4}{*}{ II } & $\mathrm{I} 23$ & 2 & 0.7 & 2 & 0.7 & 29 & 10.5 & 101 & 36.5 & 143 & 51.6 & 4.40 & .75 & \multirow{4}{*}{$\stackrel{+}{+}$} \\
\hline & $\mathrm{I} 25$ & 4 & 1.4 & 14 & 5.1 & 52 & 18.8 & 127 & 45.8 & 80 & 28.9 & 3.97 & .90 & \\
\hline & $\mathrm{I} 26$ & 2 & 0.7 & 7 & 2.5 & 24 & 8.7 & 138 & 49.8 & 106 & 38.3 & 4.24 & .76 & \\
\hline & I27 & 4 & 1.4 & 4 & 1.4 & 23 & 8.3 & 111 & 40.1 & 135 & 48.7 & 4.34 & .80 & \\
\hline \multirow{3}{*}{ III } & I1 & - & - & 18 & 6.5 & 45 & 16.2 & 133 & 48.0 & 81 & 29.2 & 4.00 & .84 & \multirow{3}{*}{ ă } \\
\hline & $\mathrm{I} 3$ & 6 & 2.2 & 15 & 5.4 & 52 & 18.8 & 124 & 44.8 & 79 & 28.5 & 3.92 & .94 & \\
\hline & I5 & - & - & 3 & 1.1 & 26 & 9.4 & 127 & 45.8 & 121 & 43.7 & 3.98 & .86 & \\
\hline \multirow{4}{*}{ IV } & I7 & 2 & 0.7 & 15 & 5.4 & 61 & 22.0 & 122 & 44.0 & 77 & 27.8 & 3.98 & .88 & \multirow{4}{*}{$\stackrel{0}{\underset{\sigma}{\sigma}}$} \\
\hline & I8 & 5 & 1.8 & 10 & 3.6 & 48 & 17.3 & 105 & 37.9 & 109 & 39.4 & 4.14 & .93 & \\
\hline & $\mathrm{I} 16$ & 1 & 0.4 & 6 & 2.2 & 32 & 11.6 & 116 & 41.9 & 122 & 44 & 4.32 & .77 & \\
\hline & $\mathrm{I} 17$ & 2 & 0.7 & 10 & 3.6 & 41 & 14.8 & 114 & 41.2 & 109 & 39.4 & 4.20 & .85 & \\
\hline \multirow{3}{*}{$\mathbf{V}$} & $\mathrm{I} 2$ & - & - & 7 & 2.5 & 25 & 9.0 & 117 & 42.2 & 128 & 46.2 & 4.32 & .74 & \multirow{3}{*}{$\stackrel{\overbrace{}}{\ddot{\gamma}}$} \\
\hline & I4 & 1 & 0.4 & 6 & 2.2 & 44 & 15.9 & 140 & 50.5 & 85 & 30.7 & 4.09 & .76 & \\
\hline & I6 & - & - & 3 & 1.1 & 26 & 9.4 & 127 & 45.8 & 121 & 43.7 & 4.32 & .68 & \\
\hline
\end{tabular}

I: Working Conditions, The Development and Happiness of the Employee, II: Sustainable Employment Policies, III. Environmental Consciousness, IV: Flexibility Applications, V: Paperless-Digital Processes

1: Not Important in Anyway 2: Not Important 3: A Little Bit Important 4: Important 5: Very Important 
According to the findings from Table 8, the items considered by the participants as the most important items among Sustainable HRM practices are considered respectively as, M21 (taking precautions required for occupational safety of employees, $\mathrm{x}^{-}=4.56$ ), M22 (importance attached on health and quality of life of employees, $x^{-}=4.49$ ), M20 (appropriateness of workplaces for physically and psychologically comfortable work activities, $\mathrm{x}^{-}=4.42$ ), M12 (presenting opportunities to employees for developing their careers, $\mathrm{x}^{-}=4.42$ ), $\mathrm{M} 18$ (providing healthy foods to employees in restaurants of enterprises, $x^{-}=4.42$ ), M23 (importance attached on work-life balance of employees, $x^{-}=4.40$ ) and M27 (executing employment policies in accordance with talent management, $\mathrm{x}^{-}=4.34$ ). According to this, it can be said that occupational health and safety, quality of life, development and happiness and talent management are more important issues for definition of Sustainable HRM.

The items perceived with a level of significance for defining Sustainable HRM are respectively as; M3 (encouraging mass transportation, personnel service, bicycle and etc. means of transportation for accessing an enterprise, $x^{-}=3.92$ ), M25 (conducting activities for facilitating adaptation of employees to post-retirement life, $x^{-}=3.95$ ), M5 (questioning environmental consciousness of employees for recruitment, $\mathrm{x}^{-}=3.98$ ) and $\mathrm{M} 7$ (determining job interview times with flexibility to be selected by a candidate, $x^{-}=3.98$ ). According to this, it can be said that environmental issues and practices to provide environmental outputs and the practices expressing long-term future for general part of participants such as post-retirement life are not perceived with priority for Sustainable HRM, yet.

The dimensions considered the most important for defining Sustainable HRM are "working conditions, development and happiness of employees" $\left(\mathrm{x}^{-}=4.38\right)$, "sustainable employment policies" $\left(\mathrm{x}^{-}=4.24\right)$, "paperless-digital processes" $\left(\mathrm{x}^{-}=4.23\right)$, "flexibility practices" $\left(\mathrm{x}^{-}=4.16\right)$ and "environmental consciousness" $\left(\mathrm{x}^{-}=3.97\right)$.

The evaluations related with existence/nonexistence status of Sustainable HRM practices in enterprises are presented in Table 9.

Table 9: Findings on Status of Existence of Sustainable HRM Practices in Enterprises

\begin{tabular}{|c|c|c|c|c|c|c|c|c|c|}
\hline \multirow{2}{*}{$\begin{array}{c}\text { Items } \\
\text { n }\end{array}$} & & \multicolumn{2}{|c|}{$\mathbf{A}$} & \multicolumn{2}{|c|}{ PA } & \multicolumn{2}{|c|}{ UA } & \multicolumn{2}{|c|}{ PDF } \\
\hline & & $\%$ & $\mathrm{n}$ & $\%$ & $\mathrm{n}$ & $\%$ & $\mathrm{n}$ & $\%$ & $\mathrm{n}$ \\
\hline \multirow{11}{*}{$\begin{array}{l}\text { Working Conditions, } \\
\text { The Development } \\
\text { and Happiness of the } \\
\text { Employee }\end{array}$} & I9 & 55 & 37.7 & 43 & 29.5 & 55 & 37.7 & 16 & 11.0 \\
\hline & $\mathrm{I} 10$ & 74 & 50.7 & 38 & 26.0 & 12 & 8.2 & 7 & 4.8 \\
\hline & I11 & 48 & 32.9 & 59 & 40.4 & 21 & 14.4 & 3 & 2.1 \\
\hline & I12 & 62 & 42.5 & 52 & 35.6 & 13 & 8.9 & 4 & 2.7 \\
\hline & I13 & 50 & 34.2 & 57 & 39.0 & 19 & 13.0 & 5 & 3.4 \\
\hline & I18 & 81 & 55.5 & 28 & 19.2 & 20 & 13.7 & 2 & 1.4 \\
\hline & I19 & 44 & 30.1 & 43 & 29.5 & 39 & 26.7 & 5 & 3.4 \\
\hline & $\mathrm{I} 20$ & 49 & 33.6 & 51 & 34.6 & 28 & 19.2 & 3 & 2.1 \\
\hline & I21 & 114 & 78.1 & 13 & 8.9 & 1 & 0.7 & 3 & 2.1 \\
\hline & I22 & 78 & 53.4 & 40 & 27.4 & 11 & 7.5 & 2 & 1.4 \\
\hline & I24 & 60 & 41.1 & 43 & 29.5 & 24 & 16.4 & 4 & 2.7 \\
\hline
\end{tabular}


Table 9 continued

\begin{tabular}{|c|c|c|c|c|c|c|c|c|c|}
\hline \multirow{4}{*}{$\begin{array}{l}\text { Sustainable } \\
\text { Employment Policies }\end{array}$} & $\mathrm{I} 23$ & 51 & 34.9 & 51 & 34.9 & 27 & 18.5 & 2 & 1.4 \\
\hline & $\mathrm{I} 25$ & 11 & 7.5 & 28 & 19.2 & 86 & 59.8 & 6 & 4.1 \\
\hline & $\mathrm{I} 26$ & 61 & 41.8 & 37 & 25.3 & 29 & 19.9 & 4 & 2.7 \\
\hline & $\mathrm{I} 27$ & 65 & 44.5 & 44 & 30.1 & 18 & 12.3 & 4 & 2.7 \\
\hline \multirow{3}{*}{$\begin{array}{l}\text { Environmental } \\
\text { Consciousness }\end{array}$} & I1 & 38 & 26.0 & 51 & 34.9 & 35 & 24.0 & 7 & 4.8 \\
\hline & $\mathrm{I} 3$ & 48 & 32.9 & 25 & 17.1 & 48 & 32.9 & 57 & 39.0 \\
\hline & I5 & 25 & 17.1 & 46 & 31.5 & 56 & 38.4 & 4 & 2.7 \\
\hline \multirow{4}{*}{ Flexibility Applications } & $\mathrm{I} 7$ & 50 & 34.2 & 60 & 41.1 & 16 & 11.0 & 8 & 5.5 \\
\hline & I8 & 27 & 18.5 & 29 & 19.9 & 59 & 40.4 & 16 & 11.0 \\
\hline & I16 & 62 & 42.5 & 38 & 26.0 & 25 & 17.1 & 6 & 4.1 \\
\hline & I17 & 47 & 32.2 & 33 & 22.6 & 47 & 32.2 & 3 & 2.1 \\
\hline \multirow{3}{*}{$\begin{array}{l}\text { Paperless-Digital } \\
\text { Processes }\end{array}$} & $\mathrm{I} 2$ & 81 & 55.5 & 39 & 26.7 & 5 & 3.4 & 6 & 4.1 \\
\hline & $\mathrm{I} 4$ & 59 & 40.4 & 48 & 32.9 & 18 & 12.3 & 6 & 4.1 \\
\hline & I6 & 74 & 50.7 & 38 & 26.0 & 11 & 7.5 & 8 & 5.5 \\
\hline
\end{tabular}

A: Available, PA: Partially Available, UA: Unavailable, PDF: Planned to Develop in the Future

The items that the participants indicated existing in their enterprises are respectively as M21 (taking necessary precautions for occupational health and safety of employees, $\%=78.1$ ), M2 (digitalization of job application procedure, \%=55.5), M18 (providing healthy foods in restaurants of enterprises, $\%=55.5$ ), M22 (importance attached on health and life quality of employees, $\%=53.4$ ) and M10 (providing regular job trainings to employees, $\%=50.7$ ). It draws attention that these practices frequently implemented in most enterprises are related with the responsibilities of HR executives which should be fulfilled at a baseline level.

The first three items indicated by the participants unavailable in their enterprises are respectively as; M25 (conducting activities for employees to adapt post-retirement life, $\%=59.8$ ), M5 (questioning employees' consciousness on environmental issues during recruitment, $\%=40.4$ ) and M8 (flexibility in working hours, $\%=88.4$ ).

The first three items indicated by the participants as partially available in their enterprises are respectively as, M7 (determining job interview hours with the flexibility to be chosen by a candidate, $\%=41.1$ ), M11 (providing employees the opportunity to participate in decision making processes, $\%=40.4$ ) and M13 (supporting employees to take part in social responsibility projects, $\%=39.3)$.

The first three items indicated by the participants as planned to be developed in their enterprises in the future are respectively as, M3 (encouraging mass transportation, personnel service, bicycle and etc. means of transportation for accessing an enterprise, \%=39), M8 (flexible working hours, $\%=11$ ) and M9 (supporting employees to take part in social responsibility projects, $\%=11)$. 
Based on the findings in Table 9, it can be said that the dimensions of "flexibility practices", "environmental consciousness" and "sustainable employment policies" take lower levels in operational practices of enterprises while an awareness has been raised by including them in future plans and practice frequency of "paperless-digital processes" dimension is higher. This is considered as an inevitable result of adaptation to technological processes, however interpreted as an overall awareness on contribution of "paperless-digital processes" in ecological environment has not been established, yet.

In order to reveal the current situation of Sustainable HRM practices in Turkey, the availability of sustainability strategies and Sustainable HRM strategies and contribution of HR department in these processes and significance level of this contribution were asked. Findings are presented in Table 10.

Table 10: Frequency and Percentage Values on Availability of a Sustainability Strategy and a Sustainable HRM Strategy, the Contribution of HRM in them and Significance Level of that Contribution

Is there a sustainability strategy in your enterprise?

\begin{tabular}{ccc}
\hline & Yes & No \\
\hline $\mathbf{n}$ & 119 & 12 \\
\hline $\boldsymbol{\%}$ & 90.8 & 9.2 \\
\hline
\end{tabular}

Is there a Sustainable HRM strategy in your enterprise?

\begin{tabular}{cccc}
\hline & Yes & No & N/A \\
\hline $\mathbf{n}$ & 86 & 44 & 1 \\
\hline$\%$ & 65.6 & 33.6 & 0.8 \\
\hline
\end{tabular}

What is the level of contribution of your HRM department in determining the sustainability strategy of your enterprise?

\begin{tabular}{ccccc}
\hline & $\begin{array}{c}\text { At every } \\
\text { phase }\end{array}$ & Partially & $\begin{array}{c}\text { No } \\
\text { Contribution }\end{array}$ & N/A \\
\hline $\mathbf{n}$ & 53 & 57 & 6 & 15 \\
\hline$\%$ & 40.5 & 43.5 & 4.6 & 11.5 \\
\hline
\end{tabular}

What is the perspective of the senior management in the support of the HR department in success of the sustainability strategy of your enterprise?

"The senior management considers the HRM support......"

\begin{tabular}{ccccccc}
\hline & $\begin{array}{c}\text { Very } \\
\text { important }\end{array}$ & Important & $\begin{array}{c}\text { A Little } \\
\text { Important }\end{array}$ & $\begin{array}{c}\text { Not } \\
\text { Important }\end{array}$ & Never & N/A \\
\hline $\mathbf{n}$ & 43 & 47 & 18 & 3 & 5 & 15 \\
\hline$\%$ & 32.8 & 35.9 & 13.7 & 2.3 & 3.8 & 11.5 \\
\hline
\end{tabular}


Within the context of Turkey, the driving and restricting force/forces leading enterprises towards Sustainable HRM practices were questioned. Findings are presented in Table 11.

Table 11: Frequency and Percentage Values Related with Driving and Restricting Forces Experienced in Sustainable HRM Practices

\begin{tabular}{|c|c|c|c|c|c|}
\hline Driving Forces & $\mathbf{n}$ & $\%$ & Restricting Forces & $\mathbf{n}$ & $\%$ \\
\hline Environmental sensitivity & 68 & 51.9 & Lack of information & 31 & 23.7 \\
\hline Social sensitivity & 74 & 56.5 & Difficulty in application & 52 & 39.7 \\
\hline Eco-efficiency & 47 & 35.9 & Cost & 54 & 41.2 \\
\hline $\begin{array}{l}\text { Sensitivity to employee } \\
\text { expectations }\end{array}$ & 74 & 56.5 & $\begin{array}{l}\text { Inadequate support of top } \\
\text { management }\end{array}$ & 25 & 19.1 \\
\hline Public restraint & 11 & 8.4 & Lack of qualified labor force & 35 & 26.7 \\
\hline Making a reputation & 36 & 27.5 & $\begin{array}{l}\text { Inadequate support of } \\
\text { human resources }\end{array}$ & 9 & 6.9 \\
\hline Competition & 56 & 42.7 & Time constraint & 49 & 37.4 \\
\hline Advertisement/Public Relations & 22 & 16.8 & Other & 4 & 3.1 \\
\hline Corporate strategies & 77 & 58.8 & Not answered & 31 & 23.7 \\
\hline Leadership of top management & 51 & 38.9 & 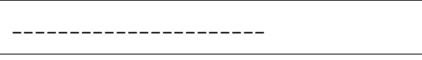 & ----- & --- \\
\hline $\begin{array}{l}\text { To keep talented candidates in the } \\
\text { institution }\end{array}$ & 79 & 60.3 & 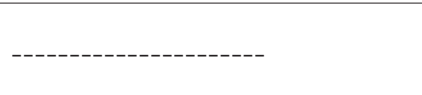 & ----- & ---- \\
\hline No idea & 1 & 0.8 & 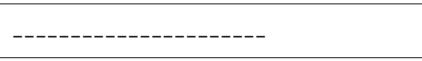 & ----- & ---- \\
\hline Other & - & - & 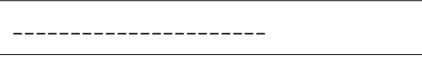 & ----- & --- \\
\hline Not answered & 18 & 13.7 & |---------------------- & $\begin{array}{ll}---- \\
--1\end{array}$ & --- \\
\hline Total & 131 & 100 & Total & 131 & 100 \\
\hline
\end{tabular}

According to perceptions of the participants, the first three driving and restricting forces leading enterprises towards Sustainable HRM are respectively presented in Table 12.

Table 12: Listing the Driving and Restricting Forces Experienced in Sustainable HRM Practices Based on Their Level of Significance

\begin{tabular}{llcclcc}
\hline & Driving Forces & $\mathbf{n}$ & $\mathbf{\%}$ & Restrictive Forces & $\mathbf{n}$ & \% \\
\hline & $\begin{array}{l}\text { Environmental } \\
\text { consciousness }\end{array}$ & 17 & 13 & Cost & 27 & 20.6 \\
\cline { 2 - 7 } $\begin{array}{l}\text { 1. } \\
\text { significance } \\
\text { level }\end{array}$ & \begin{tabular}{l} 
Corporate strategies \\
\cline { 2 - 7 }
\end{tabular} & 15 & 11.5 & $\begin{array}{l}\text { Difficulty in } \\
\text { application }\end{array}$ & 14 & 10.7 \\
& $\begin{array}{l}\text { To keep talented candidates } \\
\text { in the institution }\end{array}$ & 15 & 11.5 & Time constraint & 13 & 9.9 \\
\cline { 2 - 7 } & Total & $\mathbf{9 0}$ & Total & $\mathbf{8 3}$ \\
\hline
\end{tabular}


Table 12 continued

\begin{tabular}{|c|c|c|c|c|c|c|}
\hline \multirow{4}{*}{$\begin{array}{l}2 . \\
\text { significance } \\
\text { level }\end{array}$} & Social consciousness & 17 & 13 & $\begin{array}{l}\text { Difficulty in } \\
\text { application }\end{array}$ & 15 & 11.5 \\
\hline & Corporate strategies & 14 & 10.7 & Time constraint & 15 & 11.5 \\
\hline & $\begin{array}{l}\text { To keep talented candidates } \\
\text { in the institution }\end{array}$ & 14 & 10.7 & Cost & 10 & 7.6 \\
\hline & Total & 89 & & Total & 66 & \\
\hline \multirow{4}{*}{$\begin{array}{l}3 . \\
\text { significance } \\
\text { level }\end{array}$} & $\begin{array}{l}\text { To keep talented candidates } \\
\text { in the institution }\end{array}$ & 13 & 9.9 & Time constraint & 11 & 8.4 \\
\hline & Corporate strategies & 12 & 9.2 & $\begin{array}{l}\text { Difficulty in } \\
\text { application }\end{array}$ & 10 & 7.6 \\
\hline & $\begin{array}{l}\text { Sensitivity to employee } \\
\text { expectations }\end{array}$ & 11 & 8.4 & Lack of information & 8 & 6.1 \\
\hline & Total & 81 & & Total & 48 & \\
\hline
\end{tabular}

It has been determined that the first driving forces leading enterprises towards Sustainable HRM practices are "environmental consciousness", "social consciousness" and "keeping/attracting talented candidates in enterprise". These findings show similarity with the Triple Bottom Line Model used for representing Sustainable HRM. While, "environmental consciousness" serves environmental outputs, "social consciousness" serves social outputs, "keeping/attracting talented candidates to enterprise" serves economical outputs and these three serves for providing the triple foundation.

The restricting forces experienced by enterprises for carrying out Sustainable HRM are respectively as "cost", "implementation difficulty" and "time constraint". It can be seen from the findings that the driving forces mainly serving economical outputs such as public pressures, desire for making a reputation, advertising/public relations and etc. have less influence. Considering public pressures as a driving force with less influence in leading enterprises towards Sustainable HRM can be interpreted as that the sustainability related practices have not become prevalent to establish an isomorphism mechanism, yet.

The t-test was applied for independent samples to determine whether availability of Sustainable HRM strategy in enterprises creates a meaningful difference on perception of importance for Sustainable HRM dimensions. Findings are presented in Table 13. 
Table 13: Results of the t-Test Base on Availability of Sustainable HRM Strategy on Perception of Importance for Sustainable HRM Dimensions

\begin{tabular}{|c|c|c|c|c|c|c|c|}
\hline Dimensions & $\begin{array}{l}\text { Sus. HRM } \\
\text { Str. }\end{array}$ & $\mathbf{n}$ & $\mathbf{x}^{-}$ & SS & $\mathbf{t}$ & df & $\mathbf{p}$ \\
\hline \multirow{2}{*}{$\begin{array}{l}\text { Working Conditions, The } \\
\text { Development and Happiness } \\
\text { of the Employee }\end{array}$} & Available & 86 & 4.60 & .31 & \multirow[t]{2}{*}{10.261} & \multirow[t]{2}{*}{128} & \multirow[t]{2}{*}{.000} \\
\hline & N/A & 44 & 3.94 & .40 & & & \\
\hline \multirow{2}{*}{$\begin{array}{l}\text { Sustainable Employment } \\
\text { Policies }\end{array}$} & Available & 86 & 4.39 & .37 & \multirow{2}{*}{5.937} & \multirow{2}{*}{128} & \multirow{2}{*}{.000} \\
\hline & N/A & 44 & 3.97 & 38 & & & \\
\hline \multirow{2}{*}{$\begin{array}{l}\text { Environmental } \\
\text { Consciousness }\end{array}$} & Available & 86 & 4.18 & .43 & \multirow{2}{*}{6.245} & \multirow{2}{*}{67.797} & \multirow{2}{*}{.000} \\
\hline & N/A & 44 & 3.55 & .59 & & & \\
\hline \multirow{2}{*}{ Flexibility Applications } & Available & 86 & 4.36 & .37 & \multirow{2}{*}{8.052} & \multirow{2}{*}{128} & \multirow{2}{*}{.000} \\
\hline & $\mathrm{N} / \mathrm{A}$ & 44 & 3.76 & .44 & & & \\
\hline \multirow{2}{*}{ Paperless-Digital Processes } & Available & 86 & 4.43 & .40 & \multirow{2}{*}{8.303} & \multirow{2}{*}{128} & \multirow{2}{*}{.000} \\
\hline & N/A & 44 & 3.84 & .35 & & & \\
\hline
\end{tabular}

According to the findings in Table 13, dimensions of Sustainable HRM show a meaningful difference based on availability of a Sustainable HRM strategy. Accordingly, the perception of importance on "working conditions, development and happiness of employees", "sustainable employment policies", "environmental consciousness", "flexibility practices" and "paperless-digital processes" is higher in the enterprises with a Sustainable HRM strategy than the ones without any.

\section{Conclusions}

In this study, it is aimed to establish a conceptual framework for Sustainable HR within the context of Turkey and determine the prominent HRM subjects among sustainability reports, sustainability activities of personnel and their perception of their dimensions and the existing situation of Sustainable HRM in business practices.

In order to achieve this, three complementary studies have been carried out. In the first phase, sustainability reports were analyzed within the context of HRM subjects. Accordingly, it has been presented that the HRM practices which support sustainability activities are "occupational health and safety", "talent management", "diversity management", "performance assessment", "satisfaction and loyalty of employees", "subjective well-beings", "continuous development/training”, "voluntary participation", "work-life balance", "career management", "green practices", "additional benefits", in-house communication" and "working conditions".

Even though GRI Standards do not directly contain "the talent management" topic, "talent management" themes are frequently included in the examined sustainability reports. This can be interpreted as sustainability efforts of enterprises are associated with talent management activities of HRM. "Satisfaction and loyalty of employees", "subjective well- 
being", "voluntary participation", "work-life balance", "career management", "green practices" and etc. themes are frequently used in sustainability reports although these are non-obligatory issues in GRI Standards. This is considered as at least a part of enterprises issuing sustainability reports follow the sustainability literature in the world and transfer studies on that issue to their enterprises.

In the second phase, a Delphi technique study was conducted and it has been presented that Sustainable HRM is a concept which is address through a value-chain approach and expands the limits of HRM related practices by including stakeholders such as ecology and society as well as enterprise, organization and economy.

In the third phase of the study, the dimensions defining Sustainable HRM and current status of Sustainable HRM among management practices were presented through the Sustainable HRM questionnaire prepared by using findings from previous phases. It was determined that the Sustainable HRM questionnaire form has five sub-dimensions. These are named as "working conditions, development and happiness of employees", "sustainable employment policies", "paperless-digital processes", "flexibility practices" and "environmental consciousness".

Driving forces leading enterprises towards Sustainable HRM practices, show similarity with the Triple Bottom Line Model. While, “environmental consciousness" serves environmental outputs, "social consciousness" serves social outputs, "keeping/attracting talented candidates to enterprise" serves economical outputs and these three serves for providing the triple foundation. Considering public pressures desire for making a reputation, advertising/public relations and etc. as a driving force with less influence in leading enterprises towards Sustainable HRM can be interpreted as that the sustainability related practices have not become prevalent to establish an isomorphism mechanism, yet.

The findings of this study are limited with the enterprises and participants within the sample; although a few enterprises studying in this issue and difficulties experienced for communicating authorized persons are among the challenges for the researchers willing to work in this field, the field needs studies to fill in both its qualitative and quantitative gaps. For the academicians willing to work in this field, it is considered that the studies where the relation between the outputs of results to be created by Sustainable HRM at individual level and Sustainable HRM will fill in an important gap in the literature.

\section{References}

App, S., Merk, J., \& Büttgen, M. (2012). Employer branding: Sustainable HRM as a competitive advantage in the market for high-quality employees. Management Revue, 23(2), 262-278.

Bazzani, C., \& Canavari, M. (2013). Forecasting a scenario of the fresh tomato market in Italy and in Germany using the Delphi method. British Food Journal, 115(3), 448-459.

Boudreau, J. W., \& Ramstad, P. M. (2005). Talentship, talent segmentation and sustainability: A new paradigm for a new strategy definition. Human Resource Management, 44(2), 129-136.

Boudreau, J. W. (2003). Sustainability and the talentship paradigm: Strategic human resource management beyond the bottom line. Center for Advanced Human Resource Studies, 2-31.

Büyüköztürk, Ş. (2002). Faktör analizi: Temel kavramlar ve ölçek geliştirmede kullanımı. Kuram ve Uygulamada Ë̆itim Yönetimi, 32(32), 470-483. 
Cavagnaro, E., \& Curiel, G. (2012). The three levels of sustainability. United Kingdom: Greenleaf Publishing Limited.

Ehnert, I., \& Brewster J. C. (2014). Sustainable HRM in Europe. In I. E. Ehnert, W. Harry, K. Z. Zink (Eds.), Sustainability and HRM (pp. 339-357). New York: Springer.

Daily, B., \& Huang, S. (2001). Achieving sustainability through attention to human resource factors in environmental management. International Journal of Operations and Production Management, 21(12), 1539-1552.

Dinler, G. (2018). Sürdürülebilirlik ve insan kaynakları yönetimine yansımaları (Not Published Master's Thesis). University of Namık Kemal.

Duran, B. (2018). Sürdürülebilirlik kavramının önemi, karşılaşılan sorunlar ve şirketlerin sürdürülebilirlik raporlarının incelenmesi (Not Published Master's Thesis). University of Başkent.

Ehnert, I., \& Harry, W. (2012). Recent developments and future prospects on sustainable human resource management: Introduction to the special issue. Management Revue, 23(3), 224-239.

Ehnert, I. (2011). Sustainability and human resource management: A model and suggestions for future research. In A, Wilkinson, K. Townsend (Eds.), The future of employment relations (pp. 247271). Palgrave.

Ehnert, I. (2009). Sustainable human resource management a conceptual and exploratory analysis from a paradox perspective. New York: Springer.

Ehnert, I. (2006). Sustainability issues in human resource management: Linkages, theoretical approaches and outlines for an emerging field. 21st EIASM SHRM Workshop, March 28-29, Aston, 1-22.

Esfahani, S. A., Rezaii, H., Koochmeshki, N., \& Parsa, S. S. (2017). Sustainable and flexible human resource management for innovative organizations. Ad-Minister, 30, 195-215.

Freitas, W. R., Jabbour, C., Mangili, L. L., Filho, W. L., \& Oliveira, J. (2012). Building sustainable values in organizations with the support of human resource management: Evidence from one firm considered as the 'best place to work' in Brazil. Journal of Human Values, 18(2), 147-159.

Gollan, P. J. (2005). High involvement management and human resource sustainability: The challenges and opportunities. Asia Pacific Journal of Human Resources, 43(1), 18-33.

Gollan, P. J. (2000). Human resources, capabilities and sustainability. London School of Economics, 105. Retrieved October 5, 2016, from http://www.agrh.fr/assets/actes/2000gollan038.pdf

ILO, International Labour Organization, (2015). Yeşil ekonomide insana yaraşır işler Türkiye'den iyi işler vaka çalışması. Ankara. Retrieved March 05, 2019, from https://www.ilo.org/wcmsp5/ groups/public/---europe/---ro-geneva/---ilo-ankara/documents/publication/wcms_368300.pdf

İMSAD, İnşaat Malzemesi Sanayiciler Derneği, (2012). Türk inşaat sektöründe sürdürülebilirlik farkındalı̆̆ değerlendirme raporu. Retrieved October 5, 2019, from https://www.imsad.org/

Jabbour, C. J. C., \& Jabbour, A. B. L. S. (2016). Green human resource management and green supply chain management: Linking two emerging agendas. Journal of Cleaner Production, 112, 18241833.

Jarlström, M., Saru, E., \& Vanhala, S. (2016). Sustainable human resource management with salience of stakeholders: A top management perspective. Journal of Business Ethics, August, 1-22.

Jepsen, D. M., \& Grob, S. (2015). Sustainability in recruitment and selection: Building a framework of practices. Journal of Education for Sustainable Development, 9(2), 160-178.

Jensen, J.,Patel,P.M., \& Jake, G. (2013). High-performance work systems and job control: Consequences for anxiety, role overload, and turnover intentions. Journal of Management, 39(6), 1699-1724.

Jerome, N. (2013). Impact of sustainable human resource management and organizational performance. International Journal of Asian Socaial Science, 3(6), 1287-1292. 
Kesen, M. (2016). İşletme yönetiminde sürdürülebilir insan kaynakları yönetiminin yeri ve önemi. İnsan ve Toplum Bilimleri Araştırma Dergisi, 5(3), 554-573.

Kılıç, N., \& Vatansever, Ç. (2017). Çalışanların "yeşil” tutum ve davranışları ile yaşam değerleri ilişkisi. In T. Turgut, M. Çinko (Eds.), De ğerli insana “de ğer”li çalışmalar (pp. 1-37). Ankara: Nobel Yayınevi.

Kramar, R. (2014). Beyond strategic human resource management: Is sustainable human resource management the next approach?. The International Journal of Human Resource Management, 25(8), 1069-1089.

Koçoğlu, M., (2017). Sürdürülebilirlik çerçevesinde insan kaynakları yönetimi. In I. M. Pekdemir (Eds.), İşletmelerde sürdürülebilirlik dinamikleri (pp. 179-203). İstanbul: Beta Basım Yayım Dağıtım.

Kolk, A. (2004). A decade of sustainability reporting: Developments and significance. International Journal of Environment and Sustainable Development, 3(1), 51-64.

Konrad, A. M., Yang, Y., \& Maurer, C. C. (2016). Antecedents and outcomes of diversity and equality management systems: An integrated institutional agency and strategic human resource management approach. Human Resource Management, 55(1), 83-107.

Lülfs, R., \& Hahn, R. (2014). Sustainable behavior in the business sphere: A comprehensive overview of the explanatory power of psychological models. Organization and Environment, 27(1), 43-64.

Malthouse, E. (2001). How high or low must loadings be to keep or delete a scale item?. Journal of Consumer Psychology, 10(1-2), 81-82.

Mariappanadar, S., \& Kramar, R. (2014). Sustainable HRM: The synthesis effect of high performance work systems on organisational performance and employee harm. Asia-Pacific Journal of Business Administration, 6(3), 206-224.

Mariappanadar, S. (2003). Sustainable human resource strategy: The sustainable and unsustainable dilemmas of retrenchment. International Journal of Social Economics, 30(8), 906-923.

Masri, H. A., \& Jaaron, A. A. M. (2017). Assessing green human resources management practices in Palestinian manufacturing context: An empirical study. Journal of Cleaner Production, 143, 474489.

Mejias, A. M., Garrido, N., \& Pardo, J. E. (2015). INDITEX, a model company in the implementation of sustainable human resource management. Engineering Management and Economics, 5(1/2), 59-72.

Özutku, H., Çetinkaya, M., \& A ğca, V. (2015). İnsan kaynakları yönetimi boyutuyla kurumsal sürdürülebilirlik: BIST sürdürülebilirlik endeksindeki firmalar üzerine bir araştırma. Süleyman Demirel Üniversitesi İktisadi ve İdari Bilimler Fakültesi Dergisi, 20(3), 55-72.

Powel, C. (2003). The Delphi tecnhique: Myths and realities. Journal of Advanced Nursing , 41(4), 376382.

Prins, P., Beirendonck, L., Vos, A., \& Segers, J. (2014). Sustainable HRM: Bridging theory and practice through the "respect openness continuity (roc)" model. Management Revue, 25(4), 263-284.

Pfeffer, J. (2010). Building sustainable organizations: The human factor. Academy of Management Perspectives, February, 34-45.

Rompa, I. (2011). Explorative research on sustainable human resource management (Not Published Master's Thesis). University of Amsterdam.

Rowe, G., \& Wright, G. (1999). The Delphi technique as a forecasting tool: Issues and analysis. International Journal of Forecasting, 15, 353-375.

Savaneviciene, A., \& Stankeviciute, Z. (2014). The disclosure of sustainability and human resource management linkage. Human Resource Management and Ergonomics, VIII, 88-104. 
Stankeviciute, F., \& Savanevicien, A. (2018). Designing sustainable HRM: The core characteristics of emerging. Sustainability, 11(1), 1-23.

Stankeviciute, Z., \& Savaneviciene, A. (2013). Sustainability as a concept for human resource management. Economics and Management, 18(4), 837-846.

Şahin, Z., Çankaya, F., \& Karakaya, A. (2018). Sürdürülebilirlik raporlarının sektörlere ve yıllara göre analizi. Uluslararası İktisadi ve İdari İncelemeler Dergisi, 20, 17-37.

Şahin, A. E. (2001). Eğitim araştırmalarında Delphi tekniği ve kullanımı. Hacettepe Üniversitesi Eğitim Fakuiltesi Dergisi, 20, 215-220.

Tang, G., Chen, Y., Jiang, Y., Paille, P., \& Jia, J. (2018). Green human resource management practices: Scale development and validity. Asia Pacific Journal of Human Resources, 55(2), 1-10.

Uslu, Y., \& Kedikli, E. (2017). Sürdürülebilirlik kapsamında yeşil insan kaynakları yönetimine genel bir bakış. Ücüncü Sektör Sosyal Ekonomi, 52(3), 66-81.

Van Stolk, C., Staetsky, L., Hassan, E., \& Kim, C. W. (2012). Management of psychosocial risks at work. Luxemburg: EU-OSHA.

Vatansever, Ç., Kılıç, N., \& Dinler, G. (2017). Çalışanların sürdürülebilirlik davranışları ve sürdürülebilir çalışma yaşamı için insan kaynakları yönetimi: Türkiye'den iki kesit. İstanbul Üniversitesi İşletme Fakültesi İsletme İktisadı Enstitüsü Yönetim Dergisi, 29(85), 7-39.

Vehkamaki, S. (2005). The concept of sustainability in modern times. University of Helsinki Department of Forest Ecology Publications, 31, 1-33.

Wilkinson, A., Hill, M., \& Gollan, P., (2001), The sustainabilitiy debate. International Journal Operations and Production Management, 21(12), 1492-1502.

Wirtenberg, J., Harmon, J., Russell, W. G., \& Fairfield, K. D. (2007). HR's role in building a sustainable enterprise: Insights from some of the world's best companies. Human Resource Planning, 30(1), $10-20$.

Zang, Q., Sun, S., \& Zheng, X. (2019). The role of cynicism and personal traits in the organizational political climate and sustainable creativity, Sustainability, 11(1), 1-17.

Zaugg, R. J., Blum, A., \& Thom, N. (2001). Sustainability in human resource management. European Association of Personnel Management, University of Berne, 1-25. 